\title{
Integration of large-scale heat pumps in the district heating systems of Greater Copenhagen
}

Bach, Bjarne; Werling, Jesper; Ommen, Torben Schmidt; Münster, Marie; Morales González, Juan Miguel; Elmegaard, Brian

\section{Published in:}

Energy

Link to article, DOI:

10.1016/j.energy.2016.04.029

Publication date:

2016

Document Version

Peer reviewed version

Link back to DTU Orbit

Citation (APA):

Bach, B., Werling, J., Ommen, T. S., Münster, M., Morales González, J. M., \& Elmegaard, B. (2016). Integration of large-scale heat pumps in the district heating systems of Greater Copenhagen. Energy, 107, 321-334. https://doi.org/10.1016/j.energy.2016.04.029

\section{General rights}

Copyright and moral rights for the publications made accessible in the public portal are retained by the authors and/or other copyright owners and it is a condition of accessing publications that users recognise and abide by the legal requirements associated with these rights.

- Users may download and print one copy of any publication from the public portal for the purpose of private study or research.

- You may not further distribute the material or use it for any profit-making activity or commercial gain

- You may freely distribute the URL identifying the publication in the public portal 


\title{
Integration of Large-scale Heat Pumps in the District Heating Systems of Greater Copenhagen
}

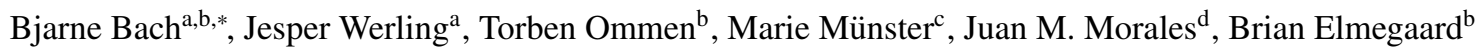 \\ ${ }^{a}$ Ea Energy Analyses A/S, Frederiksholms Kanal 4, 3.th., DK-1220 Copenhagen K, Denmark \\ ${ }^{b}$ DTU Mechanical Engineering, Technical University of Denmark, Kgs. Lyngby, Denmark \\ ${ }^{c}$ DTU Management Engineering, Technical University of Denmark, Roskilde, Denmark \\ ${ }^{d}$ DTU Compute, Technical University of Denmark, Kgs. Lyngby, Denmark
}

\begin{abstract}
This study analyses the technical and private economic aspects of integrating a large capacity of electric driven heat pumps (HP) in the Greater Copenhagen district heating (DH) system, which is an example of a state-of-the-art large district heating system with many consumers and suppliers. The analysis was based on using the energy model Balmorel to determine the optimum dispatch of HPs in the system. The potential heat sources in Copenhagen for use in HPs were determined based on data related to temperatures, flows, and hydrography at different locations, while respecting technical constraints. The Balmorel model was developed further in order to provide a better representation of HPs, for analysing the seasonal variations of COP, and to represent the difference in performance of HPs connected to either distribution or transmission networks. The optimization yields roughly 3,500 full load hours (FLH) for the HPs connected to the DH distribution networks when considering a current scenario. In a zero carbon-dioxide emission scenario expected in year 2025, approximately 4,000 FLH, are achieved. In the case where HPs are connected to the DH transmission network at elevated temperatures, their operation decreases by roughly 1,000 FLH. No significant impact was found when comparing fixed and varying operation characteristics of the HP.
\end{abstract}

Keywords:

Heat pumps, Balmorel, System analysis, District heating

\section{Introduction}

In the future, biomass and wind are expected to play dominating roles in energy systems around the globe, not least in the Danish energy system. In Denmark, the change is mainly due to a political $100 \%$ renewable energy target, which is set to be fulfilled by 2050 [1]. However, biomass resources may in the longer term be prioritized for the parts of the transport sector that cannot easily be supplied by electricity. Such a change would require a large fraction of heating and cooling to be generated from other sources. One proposed solution is increased electricity production by wind turbines and photovoltaics, and increased electricity transmission capacity to Denmark's neighboring countries in order to balance supply and demand. With a smaller fraction of thermal units for electricity production, combined heat and power plants (CHP) may no longer fulfil the desired heat demand in the large cities. This issue can be solved by converting electricity into heat, which at the same time may assist in maintaining the electricity supply/demand balance. Heat pumps may utilise the electricity from intermittent sources efficiently and are expected to play an important part in the conversion to an energy system based on renewables.

The City Council of Copenhagen agreed in 2013 on a climate plan attempting to make Copenhagen the first $\mathrm{CO}_{2}$ neutral capital by 2025[2]. A main focus is to achieve $\mathrm{CO}_{2}$ neutral district heating, as this currently supplies $98 \%$ of the heat demand of the Copenhagen municipality. This will be done by using biomass in the existing CHP plants and by implementing "new heat production units in Copenhagen" [2, p. 16].

*Corresponding author, bb@eaea.dk. 
Connecting heat pumps to the district heating systems of greater Copenhagen is supported by the municipality in order to increase the flexibility and security of supply. The increased focus on heat pumps will require knowledge of the economical and technical challenges related to implementing the technology in a large and complex district heating system.

The aim of this study is to determine if, and to what extent, heat pumps can be implemented in the district heating system of the Greater Copenhagen area. This is done by assessing the availability of heat sources in the system, and analysing the competitiveness of heat pumps for each source using the energy system model Balmorel. A detailed review on many of the available energy system models is performed by Connolly et al. [3]. Balmorel was chosen for this analysis because of its high level of detail for Danish power and heat supply, and the possibility for running hourly dispatch, which is an important factor when analysing the impact of heat pump integration in district heating systems. Balmorel is open source, which opens for the possibility to modify and model it.

When integrating combined heat and power plants with heat pumps, several configurations are possible [4]. By directly combining the two technologies, increased performance of the combined system may be achieved, compared to when operated individually, but the performance is gained at the expense of an increased amount of operational constraints for the heat pump unit. The reason for this difference is that CHP performance tends to be significantly higher compared to heat pumps operating at the same temperature level [5]. In this study, a heat pump configuration which enables heat production independently of other production units, is investigated, as heat pumps in a $100 \%$ renewable energy scenario may be most feasible to operate in periods where the fraction of combined heat and power is insufficient to cover the demand. The heat pumps will thus provide a temperature lift from the heat source temperature to the forward temperature of the district heating network.

Integration of heat pumps in district heating systems has significant focus due to the possibility for utilizing power from renewable sources efficiently. Blarke (2008) [6] sees heat pumps as the "missing link" for the Danish society in the future and introduces a concept of intermittency-friendliness. A number of energy system studies e.g., Blarke \& Lund (2007) [7], Kiviluoma \& Meibom (2010)[8], Münster et al. (2012)[9], and Blarke (2012)[10], show that heat pumps are profitable for a system. This is also found under some conditions for more detailed analyses of the plants in the system as in Ommen et al. (2014)[4] and Ommen (2015)[11], even if challenges are apparent. For other countries the potential of heat pumps as a mean to use to reach lower greenhouse gas emissions has also been acknowledged, e.g. Luickx et al. (2008)[12], Dagilis (2013)[13], Dragićević \& Bović (2009)[14], and Rinne \& Syri (2013)[15]. However, the difference between the technologies depends highly on the complete system and the conditions for renewable energy at the given time. In district heating systems based on combined heat and power, extraction steam power plants may be understood as heat pumps, because they may produce heat at the expense of power [5]. This is done at a quite high efficiency, which may make it hard for heat pumps to compete only based on efficiency.

In general heat pumps, as well as other supply technologies, will benefit from access to energy sources at highest possible temperature and consumption at lowest possible temperature. Investigations of the possible integrations is found in Ommen et al. (2014)[4] and Ommen (2015)[11]. A mapping of the heat sources available in Denmark is provided in Bühler et al. (2015)[16]. Other authors have presented similar studies for other locations in varying level of detail, e.g. Reistad (1975)[17], Bonilla et al. (1997)[18], Utlu \& Hepbasli (2007)[19], and Dupont \& Sapora (2009)[20].

Other studies of the future Copenhagen district heating system are presented in literature. These document some of the challenges to be expected by integration of heat pumps for efficient utilization of wind power.

Ommen et al. (2013)[21] showed that implementing the optimal heat pumps capacity, would give a $1.6 \%$ reduction in fuel consumption. Münster et al. (2012)[9] found in all their scenarios that individual heating will be based on heat pumps in 2025, whereas heat pump integration in the district heating system will be negligible due to the availablity of high-efficient CHP based on biomass. Both of these studies have analysed heat pumps as a homogeneous mass, and the integration does not take into consideration if there is a heat source of an appropriate size in the area where the modeled heat pump was placed. Instead of optimising the location and capacity of heat pumps, it is relevant to investigate how competitive they are, if placed in areas where the capacities are actually physically possible to integrate with potential heat sources other than air.

Other studies of heat pump integration in Copenhagen have assumed a constant Coefficient of Performance (COP) in the simulations, e.g. Münster et al. (2012)[9], Ommen et al. (2016)[22], Ommen et al. (2013)[21], and Hedegaard \& Münster (2013)[23]. Heat pumps utilising natural heat sources will in most cases experience variations in temperature of the source stream which influences both COP and capacity of the heat pump. For the sink stream (the 
DH network), capacity constraints of the district heating network necessitate increasing temperatures under winter conditions, resulting in decreased COP for these periods. In order to investigate the impact of varying heat pump performance based on both source and sink variations, both fixed and variable performance is considered to investigate how this impacts the results.

Furthermore, the location of the heat pumps in the network is investigated. The network consists of one transmission network at high temperature, which connects the largest of the production units, and the distribution networks which supplies heat to the consumers. It is important to determine whether the heat pumps should be integrated into the distribution network or the transmission network. Connecting heat pumps to the distribution network has the advantage that the temperature lift is lower, i.e. the COP is higher. Connecting them to the transmission network gives a lower COP, but the production is not limited to the distribution area demand, i.e. it can compete with neighboring generation technologies on a bigger market.

The paper thus has three main objectives:

1. to determine if integration of heat pumps is competitive in the district heating system when also focusing on the variable costs

2. to determine if it is better to connect heat pumps to the district heating distribution or transmission network

3. to determine the impact of a season-dependent COP on the results compared to a simpler assumption of constant $\mathrm{COP}$

The paper is organized as follows. Section 2 presents the methodology of the study providing a description of the district heating system analysed, explanation and building of scenarios, obtained data and assumptions, and description, development and verification of the setup of Balmorel. Section 3 shows and discusses results for the scenarios in the current (2013) and a future (2025) system. Section 4 is a more detailed discussion of the study, methodology and results. Lastly, section 5 concludes the paper.

\section{Method}

The integration of heat pumps in the district heating system of Greater Copenhagen is analysed with the energy dispatch model Balmorel. Four scenarios are set up to analyse the three objectives explained in the introduction.

\subsection{The Balmorel model}

The model used for the system analysis is Balmorel, which is an energy systems analysis model, with focus on electricity and heat, developed by Ravn et al. in 2001[24]. It is a bottom-up economical dispatch model that minimizes the system cost (operational and maintenance, emission, and fuel costs). Balmorel assumes perfect competition in the system, and is deterministic, such that it assumes perfect foresight with regards to consumer demand, power production from renewable sources and investment costs of different technologies. The model was developed for analysing the Baltic Sea region, but has over time been expanded and has also been used in projects covering many other countries, e.g. Ireland and Great Britain [25], mainland Europe [26], East Africa [27], South Africa [28], and China [29].

Balmorel has different versions used for different types of studies. Add-ons can be applied for time aggregation, unit commitment, investments, policy requirements, etc. The Balmorel setup for this study optimizes each week in an hourly resolution (168 hours per week). To improve running time, 12 weeks are chosen to represent each month. An add-on, 'heattrans' developed by Hans Ravn is applied for a detailed description of the heat transfer between areas. The add-on makes it possible to create production and consumer areas, and to connect these with each other[30]. A schematic representation of the system modeling structure (input/output) are in Figure 1.

For this study the model is further developed to describe the seasonal fluctuations in the COP of heat pumps, and to make it possible to analyse heat pumps connected to both the transmission and distribution networks. This is further described in section 2.6 


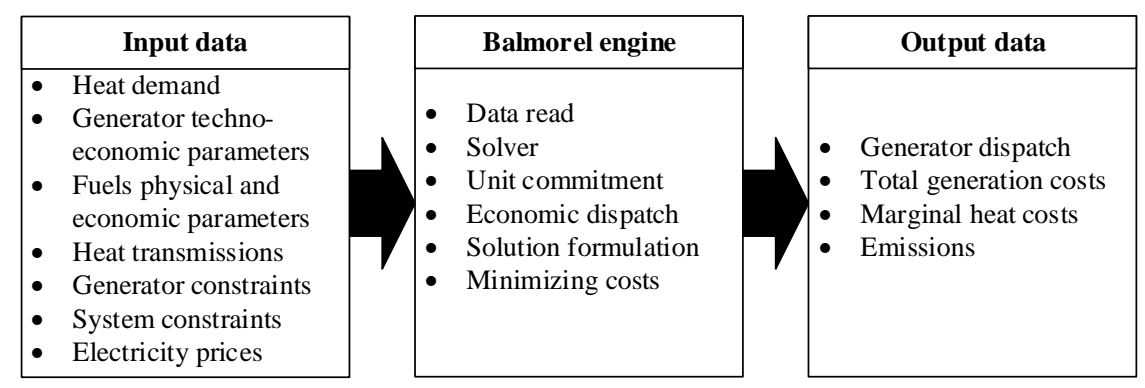

Figure 1: The system modeling structure of Balmorel specifically for this study.

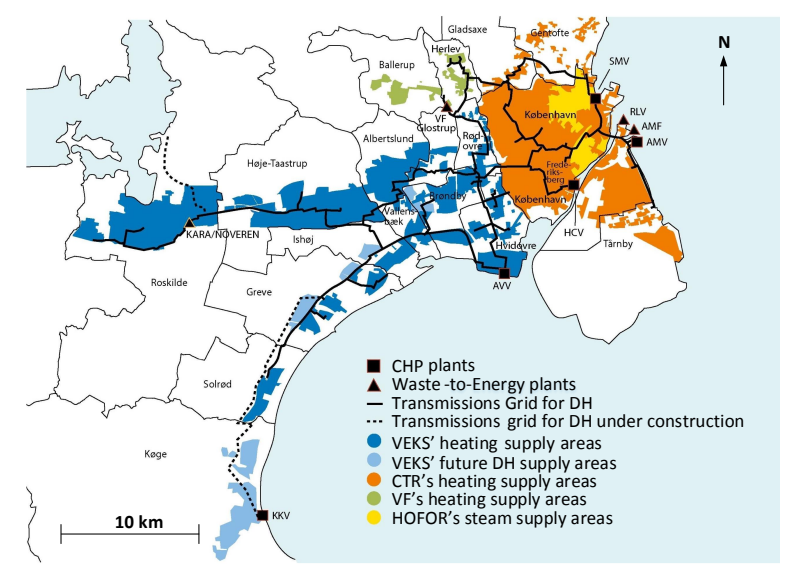

Figure 2: Map of the district heating network of the Greater Copenhagen area [32]

\subsection{The analysed district heating system}

The district heating network of Greater Copenhagen covers a large area, as shown in Figure 2 The network is comprised of four suppliers: Metropolitan Copenhagen Heating Transmission Company (CTR), Vestegnens Kraftvarmeselskab (VEKS), Hovedstadens Forsyning (HOFOR), and Vestforbrænding (VF). In Figure 2 the companies' supply areas are shown. In central Copenhagen (HOFOR and CTR), 98\% of all consumers use district heating as their heat supply[31].

The district heating network consists of a number of smaller distribution areas supplying the individual households with heat (demand shown in Figure 3). The transmission network (shown in Figure 2) supplies heat to heat exchangers in these distribution areas from the producers (e.g. CHP plants). The forward temperature levels of the two networks are very different. In the transmission network the temperatures are high, i.e. approximately $100^{\circ} \mathrm{C}$, whereas the temperature of the distribution network is approximately $60^{\circ} \mathrm{C}$. CTR, VEKS and HOFOR cooperate in Varmelast.dk to ensure that the load of the CHP plants in the metropolitan area are distributed via a global economic optimization[33].

The generation plants and storages in Copenhagen in 2013 are shown in Table 1 The peak load of the system was $2.5 \mathrm{GW}_{\text {th }}$ in 2013 , and the total heat demand was $35 \mathrm{PJ}$ or $9.7 \mathrm{TWh}_{\mathrm{th}}$.

\subsection{Scenarios for the system analysis}

Four scenarios are set up to analyse the three aforementioned objectives. The focus of all four scenarios is the years 2013 and 2025. The scenarios are illustrated in Table 2. A reference scenario (Reference) is setup for comparison. This scenario is the current district heating system of Greater Copenhagen, and the planned system in 2025. In the first heat pump scenario (Fixed COP (dist.)) a number of heat pumps are connected to the distribution networks. 
Table 1: District heating generation technologies in the Greater Copenhagen area.

\begin{tabular}{ll}
\hline Acronym & Plant \\
\hline ARC & Amager Ressource Center CHP (waste incineration) \\
AMV1 & Amagerværket CHP plant unit 1 (wood pellets) \\
AMV3 & Amagerværket CHP plant unit 3 (coal/wood pellets) \\
AMV-HS & Amagerværket CHP plant Heat storage \\
AVV1 & Avedøreværket CHP plant unit 1 (coal/wood pellets) \\
AVV2 & Avedøreværket CHP plant unit 2 (wood pellets) \\
AVV-HS & Avedøreværket CHP plant Heat storage \\
GEO & Geothermal plant \\
HCV & H.C. Ørsted CHP plant (natural gas) \\
KARA & KARA/NOVEREN CHP (waste incineration) \\
KKV & Køge CHP plant (wood chips) \\
PL & Peak load boiler (natural gas) \\
LYN & Lynetten incineration plant (waste incineration) \\
SMV & Svanemølleværket CHP plant (natural gas) \\
VF & Vestforbrænding CHP (waste incineration) \\
\hline HP & Heat pumps (used in scenarios) \\
\hline
\end{tabular}

Table 2: Scenario explanation for the system analysis.

\begin{tabular}{lccc}
\hline & Heat pump integration & Variable/Fixed COP & Distribution/Transmission network \\
\hline Reference & no & - & - \\
Fixed COP (dist.) & yes & Fixed & Distribution \\
Variable COP (dist.) & yes & Variable & Distribution \\
Variable COP (trans.) & yes & Variable & Transmission \\
\hline
\end{tabular}

These heat pumps are analysed with a fixed yearly COP. In the second heat pump scenario (Variable COP (dist.)) the same heat pumps are analysed with variable COP, still connected to the distribution networks. In the third heat pump scenario (Variable COP (trans.)) the same heat pumps are analysed with variable COP, but this time connected to the transmission network.

\subsection{Assumptions and data for the system analysis}

The generation technologies of Greater Copenhagen consist of a total of $2000 \mathrm{MW}_{\text {th }} \mathrm{CHP}$ units and $100 \mathrm{MW}_{\text {th }}$ waste incineration and geothermal base load heat-only units. In addition, there is in the order of $2000 \mathrm{MW}_{\text {th }}$ peak load units for heat distributed all around the distribution areas, and $2730 \mathrm{MWh}_{\text {th }}$ heat accumulators. The physical and economical parameters for the specific plants are classified, but Table 3 shows a range of approximate values.

Fuel price scenarios are taken from IEA's World Energy Outlook 2012[35]. The $\mathrm{CO}_{2}$ prices are from scenarios made by COWI and Ea Energy Analyses for the Danish Energy Agency regarding the role of district heating in the

Table 3: Parameters of the generation technologies. Technical parameters are explained in more detail in Verbruggen et al. (2013)[34]. Fixed costs in $\mathrm{k} € / \mathrm{MW}_{\mathrm{el}}$ for back-pressure and extraction and in $\mathrm{k} € / \mathrm{MW}_{\text {th }}$ for heat-only boilers. Waste incineration plants are in the higher end of the fixed cost in the back-pressure range. Variable costs are in $€ / \mathrm{MWh}_{\mathrm{e}}$ for back-pressure and in $€ / \mathrm{MWh}_{\text {th }}$ for heat-only boilers. For back-pressure and heat-only the efficiency is the thermal fuel efficiency, and for extraction it is the electrical fuel efficiency.

\begin{tabular}{lccc}
\hline & Back-pressure & Extraction & Heat-only boilers \\
\hline Fuel efficiency, $\boldsymbol{\eta}$ & $0.8-1.0$ & $0.3-0.5$ & $0.7-1.0$ \\
Power-to-heat ratio, $\boldsymbol{\sigma}$ & $0.2-0.8$ & $0.6-0.7$ & 0 \\
Used heat for generated power substitution, $\boldsymbol{\beta}$ & 0 & $0.1-0.3$ & 0 \\
Fixed cost & $30-800$ & $15-150$ & $3-80$ \\
Variable cost & $0.7-13.0$ & $0.7-13.0$ & $0.7-13.0$ \\
\hline
\end{tabular}




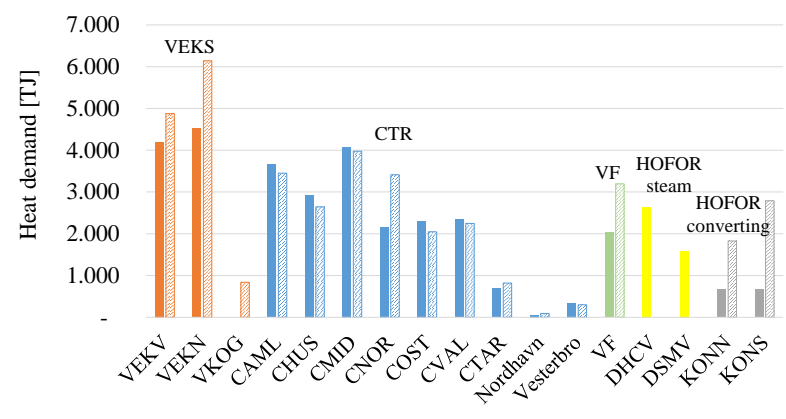

Figure 3: Heat demand in 2013 (filled) and 2025 (shaded) 37

future Danish energy system[36]. For 2013, historical taxes are used. For 2025, historical Danish legislative practices are assumed to continue, i.e. electricity subsidies are deflating over time, and taxes are kept constant in fixed prices. Distribution and transmission tariffs have not been included in the model. The annual heat demand of the areas for 2013 and 2025 can be seen in Figure 3 37]. The current steam areas (DHCV and DSMV) are assumed to be converted to water-based district heating before 2025, and their future heat demands are assigned to HOFOR's areas. Figure 4 displays the networks analysed in for 2013 and 2025. The circles in the figure indicate heat generation areas (see Table 1), and the squares indicate distribution areas. The lines indicate transmission connections, and the number represent the capacity of the connection. INF stands for infinite, i.e. no transmission limitation. Some connections are one-way, e.g. from production areas such as AVV, or between consumer areas, such as the connection from VF to VEKN.

To improve the simulation time of the model, and to clarify the impact on the scenario changes, an electricity price profile for 2013 and 2025 is applied for Eastern Denmark. In this way, it is not needed to include all of the Nordic countries in every optimisation run. The 2013 electricity price profile is from Nord Pool Spot[38], and the time weighted average was $39.7 € / \mathrm{MWh}_{\mathrm{el}}$.

The 2025 electricity price profile is obtained by running an investment optimization in Balmorel with the Nordic Countries plus Germany. In the investments run, data from the Nordic Countries regarding decommissioning of plants and forecasts of electricity and heat demand[39], are used. Investments in new fossil fuel plants are not allowed in Denmark. To optimize the simulation time, the year of the investment simulation (2025) is split into four seasons and is time aggregated. The investments made in that simulation are then used as base case for parameters (generation capacity, transmissions, etc.) in the second run, which uses the highest resolution so that an hourly spot price throughout the year is obtained. This include $50 \%$ extra wind capacity, refurbishment of half the coal capacity to biomass, construction of four times as much new biomass capacity, and three times as much photovoltaics as in 2012. In Figure 5, the obtained price profile from the simulation is shown. The time weighted average is $41.0 € / \mathrm{MWh}_{\mathrm{el}}$.

This electricity price is significantly below the forecast from the Danish Energy Agency socioeconomic preconditions from 2014[40], which are approximately $60 € / \mathrm{MWh}_{\mathrm{el}}$, but significantly higher than the Nord Pool (Nasdaq) forward prices for 2025 of approximately $30 € / \mathrm{MWh}_{\mathrm{el}}$ (from July 2015)[41]. The Danish Energy Association published a scenario report in 2014, where they with similar assumptions as the ones used in this paper, and by use of Balmorel, found an electricity spot price of ca. $40 € / \mathrm{MWh}_{\mathrm{el}}$ in their base case future scenario[42].

To optimize the simulation time only one week in each month was simulated. The specific weeks are chosen to be the last week in each month. The weekly values are assumed to be valid for the whole month.

\subsection{Heat sources and heat pump efficiencies}

Bach (2014)[44] determined the available heat sources for heat pumps in the Copenhagen region. Three main sources exist: Drinking water, sewage water and sea water. It is possible to install $3 \times 4.5 \mathrm{MW}_{\text {th }}$ (output - assuming a COP of 3) heat pumps based on the drinking water network. $27 \mathrm{MW}_{\text {th }}$ and $60 \mathrm{MW}_{\text {th }}$ are available at sewage water treatment plants at Damhusån (CVAL) and Lynetten (CAML), respectively. 
(a)

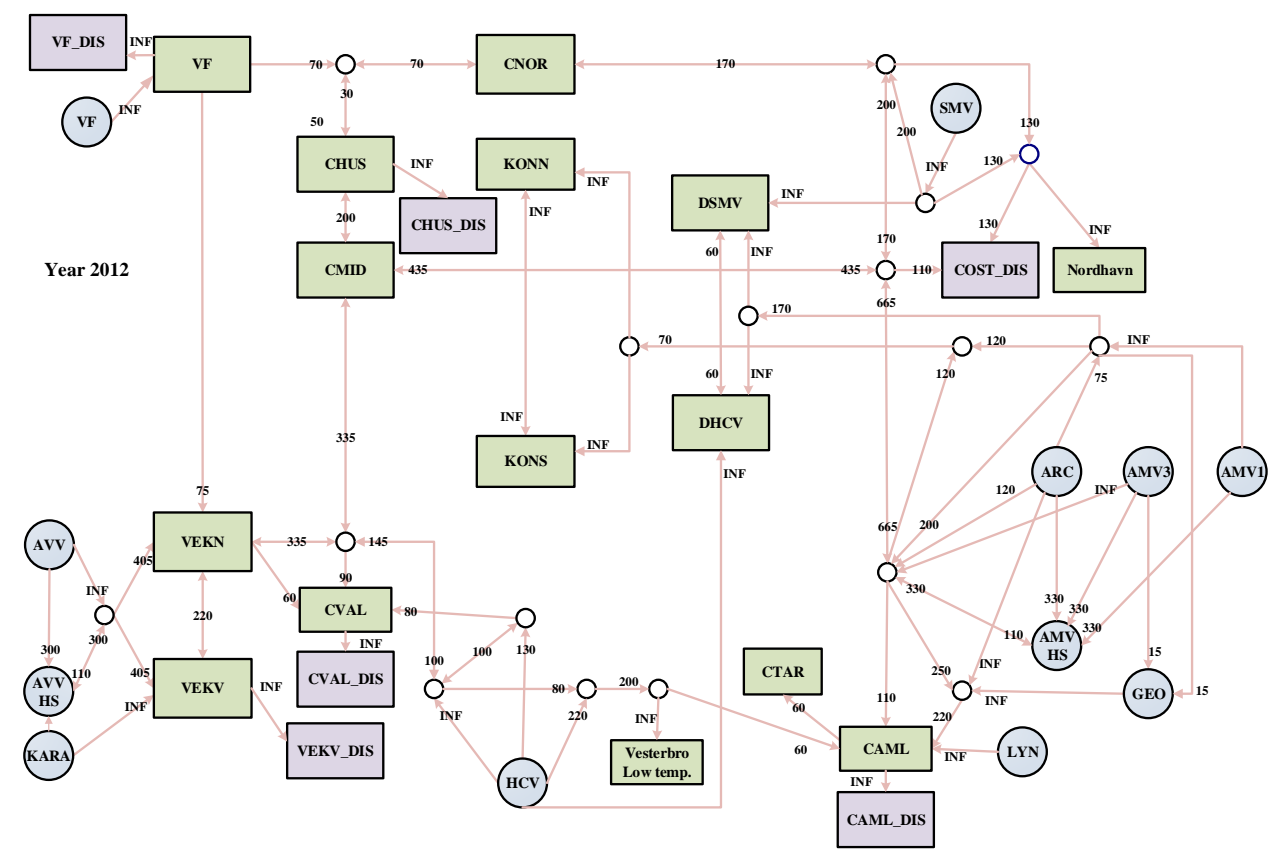

(b)

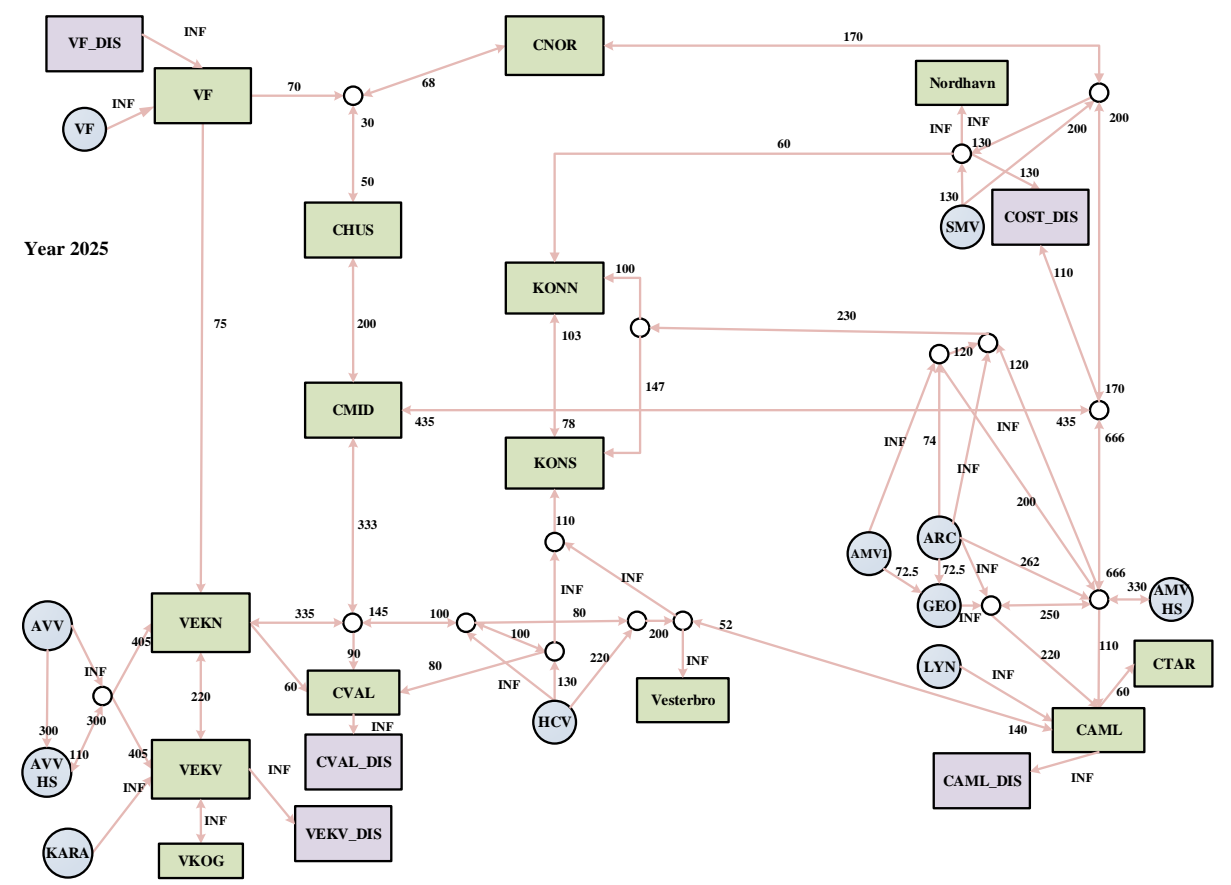

Figure 4: Structure and connections in the district heating transmission network of the Greater Copenhagen area in (a) 2012 and (b) 2025. See Table 4 and Table 1 for an explanation of distribution areas and generation technologies respectively. Circles represent production areas and squares consumer (distribution) areas. Numbers represent the transmission capacity between different areas. INF indicates infinite capacity, meaning that there is no restriction on capacity than set by the equipment used for providing the heat to the heat pump, e.g., pumping power and pipelines. These infinite connections are used as functional 'one-way' connections and are not there in reality. [43] 


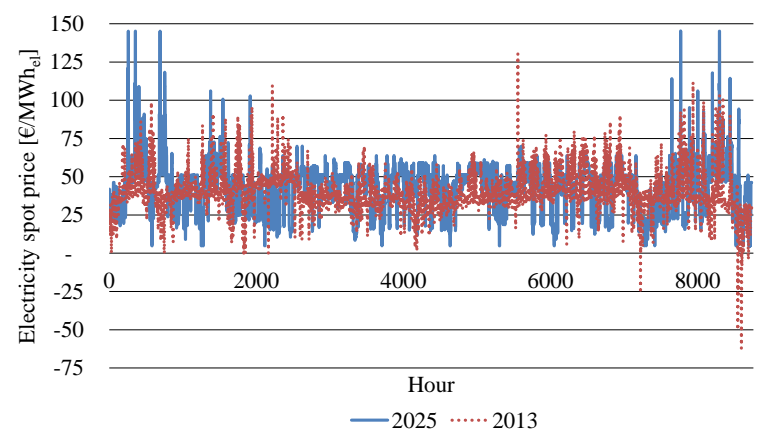

Figure 5: Electricity price profile for 2013 and 2025. The 2013 profile is from Nordpool Spot[38]. The 2025 profile is calculated in Balmorel based on the base case parameters.

Table 4: Greater Copenhagen consumer areas in Balmorel[43].

\begin{tabular}{ll}
\hline Name & Areas \\
\hline VEKS & \\
VEKV & Roskilde/Hedehusene/Taastrup \\
VEKN & Hvidovre/Glostrup/Albertslund \\
CTR & \\
CAML & Amagerland \\
CHUS & Brønshøj/Husum/Vanløse \\
CMID & Frederiksberg/Nørrebro \\
CNOR & Gladsaxe/Gentofte \\
COST & Østerbro \\
CVAL & Valby \\
NORDHAVN & Nordhavn \\
VESTERBRO & Vesterbro \\
CTAR & Tårnby \\
VF & \\
VF & Herlev/Ballerup \\
HOFOR & \\
DHCV & Steam Centrum \\
DSMV & Steam Østerbro \\
KONN & Converting area North “Østerbro" \\
KONS & Converting area South “Centrum” \\
\hline
\end{tabular}


Table 5: Distribution of heat pumps in the district heating system of Greater Copenhagen.

\begin{tabular}{llc}
\hline Area & Heat source & Capacity $\left[\mathbf{M W}_{\text {th }}\right]$ \\
\hline CAML & Sewage water & 60.0 \\
CVAL & Sewage water & 27.0 \\
CHUS & Drinking water & 4.5 \\
VEKV & Drinking water & 4.5 \\
VF & Drinking water & 4.5 \\
CAML & Sea water & 70.0 \\
COST & Sea water & 90.0 \\
\hline Total & & $\mathbf{2 6 0 . 5}$ \\
\hline
\end{tabular}

Table 6: COP of the heat pumps averaged according to demand. The COPs used in the fixed COP scenario (Fixed COP (dist.)) are the ones in the 'COP distr.' column. For the variable COP scenarios (Variable COP (dist.) and Variable COP (trans.)) the COPs shown in Figure 6 are used.

\begin{tabular}{lccc}
\hline Technology/Source & COP distr. & COP trans. & Difference \\
\hline Sewage water & 3.2 & 2.6 & $25 \%$ \\
Drinking water & 3.1 & 2.6 & $20 \%$ \\
Sea water & 2.9 & 2.5 & $17 \%$ \\
\hline
\end{tabular}

There is in theory an infinite potential of heat by using sea water as source, but there is, of course, a consumer limitation of how much heat can be extracted and consumed in the distribution area. An analysis of the heat duration curves for the consumer (distribution) areas CAML and COST, yields capacities of $130 \mathrm{MW}_{\text {th }}$ in CAML, and $90 \mathrm{MW}_{\text {th }}$ in COST when connected to the distribution network. In the analysis it is assumed that the heat pumps would be base load and the marginal output should have 4,000 FLH, i.e. the 4,000 hours are used in the duration curve to find the marginal heat consumption. This consumer limitation is not present when connecting to the transmission network, but the same capacities are chosen for similarity. This gives the distribution of heat pumps by area shown in Table 5 . The total of $260.5 \mathrm{MW}_{\text {th }}$ then covers around $10 \%$ of the systems winter peak. The table indicates the total amount of heat pump capacity installed in each area. It may consist of a number of separate heat pumps.

The COP is calculated by assuming a two-stage compression heat pump using ammonia as refrigerant. The thermodynamic calculations of the cycle in the dimensioning (designing) phase follows the steps of dimensioning a refrigeration system as explained in many textbooks, e.g. Dincer \& Kanoglu (2010)[45]. In the part-load (offdesign) phase the dimensions of the heat exchangers are fixed and the temperatures in the cycle vary accordingly. The temperatures of the heat sources are shown in Figure $6(a)$ together with the forward temperatures of the district heating water in the transmission and distribution network (estimated from coherence between forward temperatures and outdoor air temperature given from HOFOR[46, 47]). The dimensioning case is for winter operation at temperatures of the heat pumps. The seasonal variations of COP when connected to the distribution and transmission networks are shown in Figure 6 $(b)$. Overall, the COPs for the heat pumps connected to the distribution network are $17 \%$ to $25 \%$ higher than when connected to the transmission network.

The value of COP used for simulations with fixed COP connected to the distribution network scenario (Fixed COP (dist.)) is the demand-weighted average shown in Table 6

The variable costs for operation and maintenance of the heat pumps are assumed to be similar to those in the study made by Karlsson \& Meibom (2008) [48], which is $1.2 € / \mathrm{MWh}_{\mathrm{th}}$.

\subsection{Modeling in Balmorel}

We have further developed a more detailed description of heat pumps in the Balmorel model that capture the variation in COP over time. Equations (1) and (2) present the fuel consumption rate equations utilised in Balmorel. The addition to the standard Balmorel model, is that we use generation efficiencies, $\eta$, that depend on the network and ambient temperatures and thus vary over time, $\eta_{g, t}$. This original contribution to the model is further described in Bach (2014) [44]. 

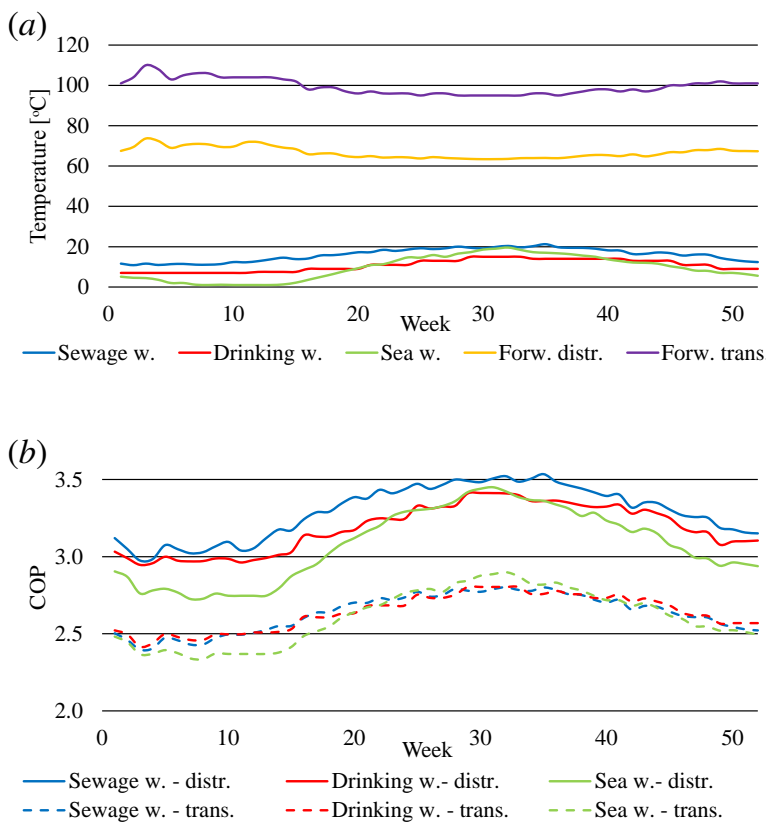

Figure 6: (a) Temperatures of heat sources and district heating forward temperatures of transmission and distribution network. Data from HOFOR 46 49], DMI 47, 50], and MacAller (2013)[51]. . (b) Seasonal COP for the different technologies connected to distribution network and transmission network.

$$
\begin{aligned}
& V_{a, g, t}^{\text {con.fuel }}=\frac{V_{a, g, t}^{\text {gen.el. }}+V_{a, g, t}^{\text {gen.heat }} Z_{g}}{\eta_{g, t}^{\text {gen. }}}, \quad \forall a, t,\left(g \in \mathbb{G}^{\text {th. }}\right) \\
& V_{a, g, t}^{\text {dem.,el. }}=\frac{V_{a, g, t}^{\text {gen.heat }}}{\eta_{g, t}^{\text {gen. }}}, \quad \forall a, t,\left(g \in \mathbb{G}^{\text {e.h. }}\right),
\end{aligned}
$$

where the sets, parameters and variables are described in Table 7 The $\beta$-value for an extraction steam turbine is defined as the loss of electricity production, when the heat production is increased one unit at constant fuel input[34]. For extraction units the efficiency, $\eta_{g, t}^{\text {gen. }}$, is defined as the electricity efficiency, and for all others it is defined as the total energy utilisation.

To determine the difference between connecting the heat pumps to the distribution or transmission network, distribution areas are defined individually in the model and all other areas are defined as transmission areas (see the areas in Figure 4). The distribution areas are then connected to the transmission network with a one-way distribution line with unlimited heat transfer capacity and no heat loss. Depending on the scenario, the heat pump can then be placed in the distribution area, or in the area connected to the transmission network.

\subsection{Verification of the Balmorel model}

The Balmorel setup has been validated by historical, hourly data from 2012. The electricity price profile for Eastern Denmark in 2012 is applied to the system. The operation outages of the separate power plants in 2012 are taken from the power plants' yearly environmental impact statements[52, 53, 54, 55, 56, 57, 58].

The heat production found in Balmorel for each plant is compared with historical productions in Figure 7 on a yearly basis.

Generally speaking, the production distribution between the plants is reasonable compared to the historical distribution. Out of the total production of $33 \mathrm{PJ}$, about $10 \%$ is allocated to other units by the model compared to the 
Table 7: Sets, parameters and variables.

\begin{tabular}{|c|c|}
\hline \multicolumn{2}{|l|}{ Sets } \\
\hline$a$ & Areas \\
\hline$g$ & Generation technologies \\
\hline$t$ & Time periods \\
\hline $\mathbb{G}^{\text {th. }}$ & Subset of thermal power stations $g$ \\
\hline $\mathbb{G}^{\text {e.h. }}$ & Subset of electric heating unit $g$ (incl. HP) \\
\hline \multicolumn{2}{|c|}{ Parameters } \\
\hline$Z_{g}$ & $\left\{\begin{array}{cl}\beta_{g} & \text { for extraction steam plants } g \\
1 & \text { other }\end{array}\right.$ \\
\hline$\eta_{g}^{\text {gen. }}$ & Fuel efficiency of $g[-]$ \\
\hline \multicolumn{2}{|c|}{ Variables } \\
\hline$V_{a, g, t}^{\mathrm{con}, f u e l}$ & Fuel consumption of $g$ in $a$ to $t$ [MWh] \\
\hline 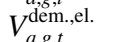 & Electricity demand of $g$ in $a$ to $t$ [MWh] \\
\hline$V_{a, g, t}^{g, g, e, e l . ~}$ & Electricity generation of $g$ in $a$ to $t$ [MWh] \\
\hline$V_{a, g, t}^{\text {gen,heat }}$ & Heat generation of $g$ in $a$ to $t[\mathrm{MWh}]$ \\
\hline
\end{tabular}

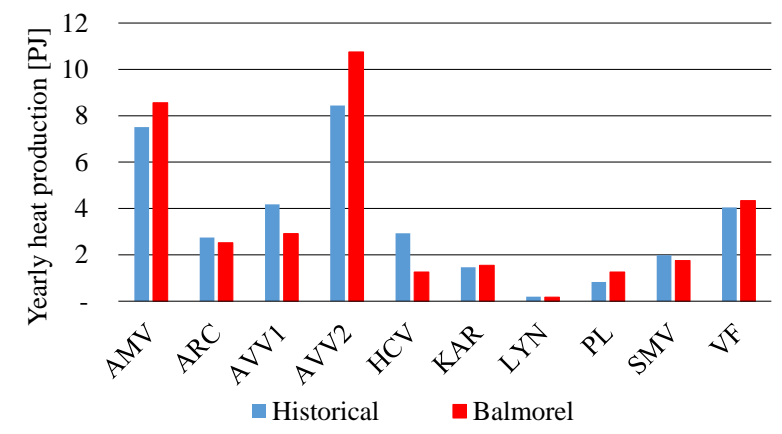

Figure 7: Comparison between historical and modelled production of heat for 2012 


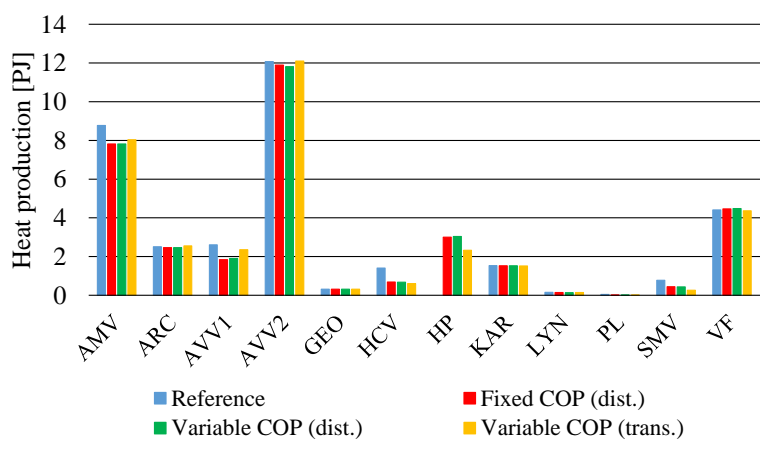

Figure 8: Heat production by unit in 2013.

historical dispatch. Production from the waste incineration (ARC, KAR, VF) plants found by Balmorel, are very close to the actual production in 2012 (roughly $\pm 7 \%$ ). The total production found from the AVV units is close to the historical production (approximately $+8 \%$ ), but the distribution between AVV2 and AVV1 does not agree completely with the historical data. The reason could be that AVV2 in 2012 still used some natural gas in its main boiler, whereas the main boiler in Balmorel is solely modelled to use wood pellets. The price of wood pellets is assumed to be lower than the price of natural gas, as well as there is no heat tax on wood pellets, which yields a higher production on AVV2 in the model. This also explains the lower production on HCV, which also runs on natural gas, and also supplies to the VEKN area.

The peak load (PL, SMV and HCV) production found with Balmorel is roughly $12 \%$ of the total production. In 2012, this number was $17 \%$ and has historically been around $10 \%$ to $20 \%$ [32].

The network description in the model is therefore deemed to reflect the total yearly productions distributed between units to a sufficient level.

\section{Results}

\subsection{Scenario results for 2013}

In Figure 8 , the total heat production distribution between units for the 2013 reference and the three scenarios are shown. Results for the AMV units are shown as a total due data confidentiality. The distribution of heat production in the reference case and for the heat pump scenarios are plotted in Figure 9. The heat pumps connected to the distribution network have a yearly heat production of roughly $3 \mathrm{PJ}$, and roughly $2.3 \mathrm{PJ}$ when connected to the transmission network. The figure illustrates from which units the heat pumps displace production. The heat production from each type of heat pumps is shown in Figure 10.

The heat pumps primarily displace production from expensive units such as SMV and HCV, which are so expensive that they can be considered as peak load units in the model. Thereafter, production by CHP plants is displaced. A heat pump is expected to produce when electricity prices are low, whereas a CHP plant will, to the extent possible, avoid producing when electricity prices are low. As such, heat pumps can improve the energy balance in a future electricity market characterized by greater price fluctuations.

The full load hours (FLH) for each type of heat pumps are shown in Figure 11. The heat pumps connected to the distribution network (Fixed COP (dist.) and Variable COP (dist.)) have roughly 3,500 FLH. The sea water heat pumps in particular have a low number of full load hours in the 2013 scenarios. The reason is the lower COP of the sea water heat pumps, and not that these heat pumps are overdimensioned. This can be seen from Figure 12 which displays the full load hours for the 2013 Variable COP (dist.) scenario compared with the same scenario, but with half of the sea water heat pump capacity. The full load hours for the sea water heat pumps only increases by approximately $3 \%$.

Connecting the heat pumps to the transmission network decreases this number to approximately 2,000 FLH to 2,500 FLH. The reason is the lower COP, and thus the higher cost of heat production. The sewage and drinking water 


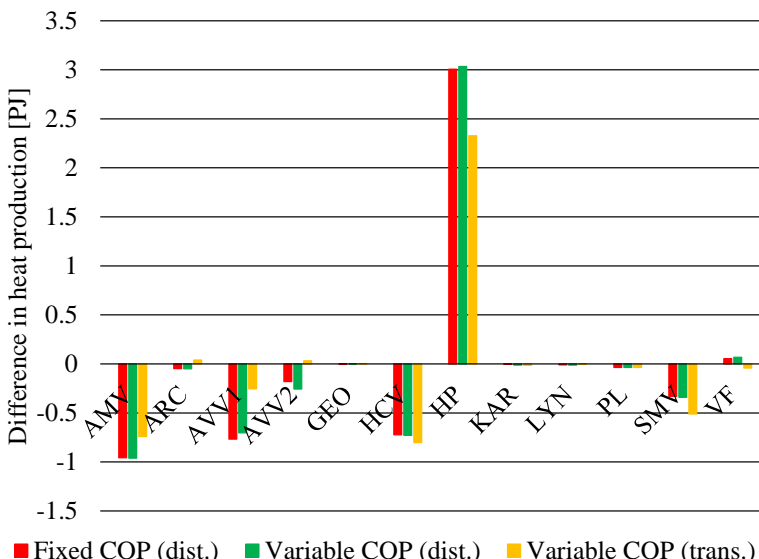

Figure 9: Difference in production from reference in 2013.

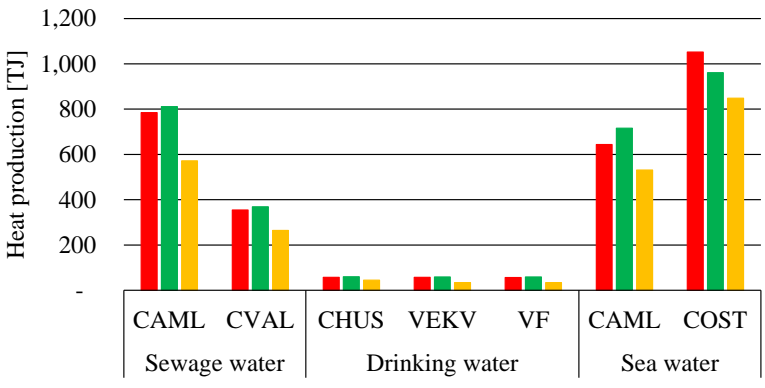

a Fixed COP (dist.) — Variable COP (dist.) $\quad$ Variable COP (trans.)

Figure 10: Heat production from each type of heat pumps in 2013. 


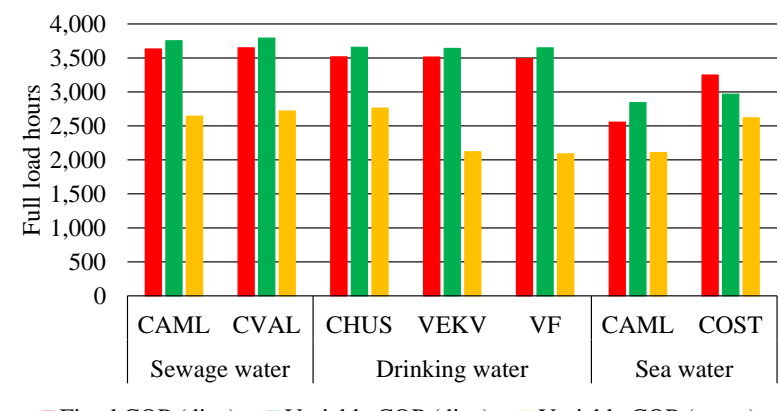

$\square$ Fixed COP (dist.) $\quad$ Variable COP (dist.) $\quad$ Variable COP (trans.)

Figure 11: Full load hours for the heat pumps in 2013.

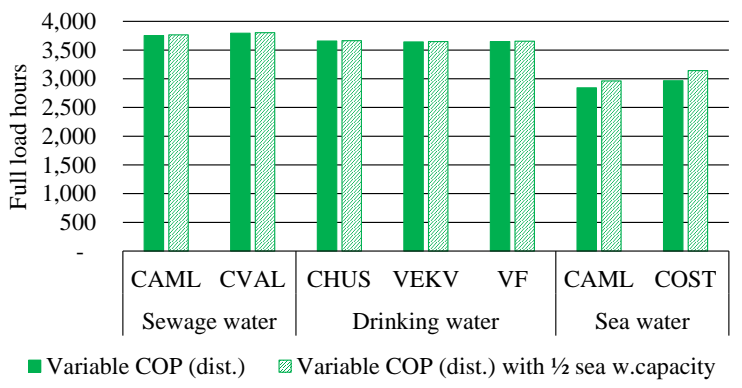

Figure 12: Full load hours for the Variable COP (dist.) 2013 scenario with all, and half, of the sea water capacities listed in Table 5

heat pumps connected to the distribution network all have around 3,500 FLH, whereas the sea water heat pumps only have 3,000 FLH.

The monthly productions from each technology (sewage, drinking and sea water) are shown in Figure 13. The distribution network connected heat pumps (dist.) with fixed COP and variable COP follow each other most months. An exception is for sewage water heat pumps in May. Here the heat pumps with variable COP produce twice the amount compared to the heat pumps with fixed COPs. In Figure 14 it can be seen that in May the sewage water heat pumps displace production from the AMV units in the Variable COP scenario compared to the Fixed COP. The COP of the sewage water heat pumps in the Fixed COP (dist.) scenario are fixed to 3.2 all year around, where as the COP of the same heat pumps in the Variable COP (dist.) scenario are 3.4 in May. This $6 \%$ increase in efficiency changes the competitiveness between the CHP plant AMV and the sewage water heat pumps, so the heat pump double their heat production in the Variable COP (dist.) case.

There are no significant differences between the fixed and variable COP scenarios when they both are connected to the distribution network (except for one sewage water heat pumps in May). The likely reason for this is that the COP does not change much over time. The COP only changes by a few percent from one week to the next due to the inertia of the temperature of the source water.

The heat pumps connected to the transmission network produce significantly less compared to the ones connected to the distribution network. This is particularly the case for February, March, and November where heat production is significantly lower. In the summer however, there is not much difference, and in June the sea water heat pumps actually produce more when connected to the transmission network. It is particularly the sea water heat pump at CAML that increases its production when connected to the transmission network as seen in Figure 13. The sea water heat pump does not displace CHP in these periods. Instead it displaces some of the lost heat production from the sewage water heat pump placed in the same area (CAML). This can be seen in Figure 15. The sea water heat pumps regain about half of the lost heat production by the sewage water heat pump. The reason for the shift in competitiveness is that the COP of the sea water heat pumps is marginally better than the sewage water heat pumps, when connected to the 

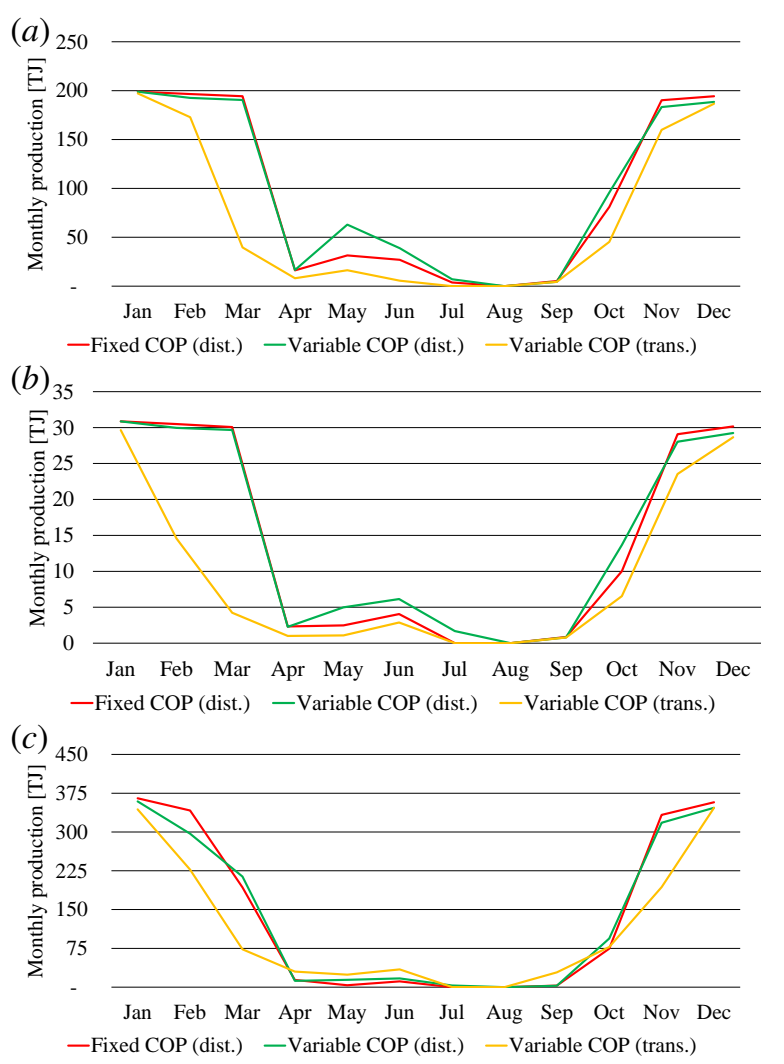

Figure 13: Total monthly production in 2013 for heat pumps using (a) sewage water, $(b)$ drinking water, and $(c)$ sea water.

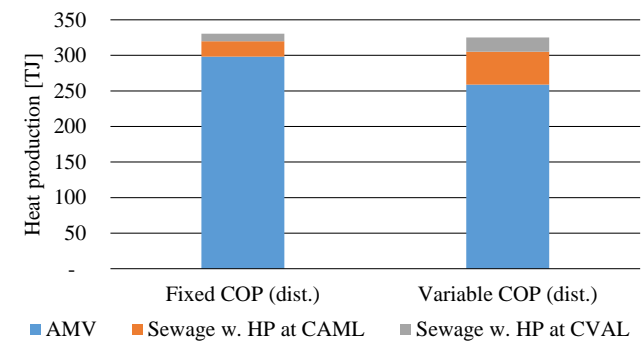

Figure 14: Heat production from AMV, and the sewage water heat pumps in May 2013. 


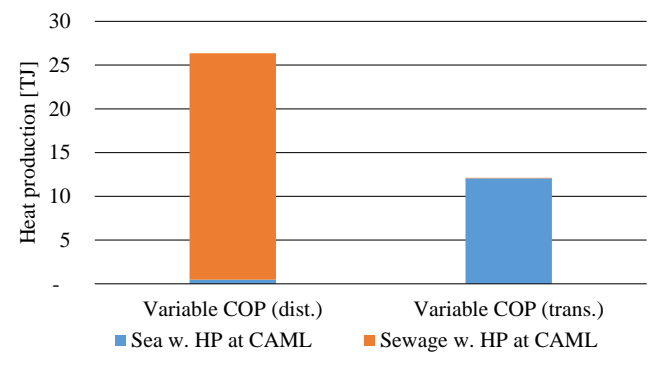

Figure 15: Production of heat from AMV and sea water heat pumps in June 2013.

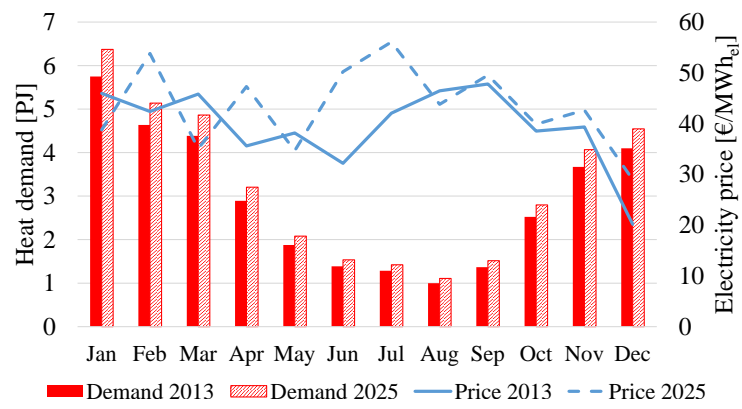

Figure 16: The heat demand and electricity prices for 2013 (filled) and 2025 (dashed).

transmission network (as seen in Figure 6). The COPs are however so similar, that it would be more accurate to say that the heat pumps located at CAML in total lose half of their heat production.

\subsection{Scenario results for 2025}

The differences in heat production for 2025 compared to the reference are shown in Figure 17 In 2025, the heat pumps mainly displace peak load (PL) production, and production from AMV1, which is the most expensive CHP unit in the system. The total heat production by heat pumps is roughly $3.3 \mathrm{PJ}$ when connected to the distribution network, and 2.6 PJ when connected to the transmission network.

The heat pumps mainly displace peak load production $(\sim 1.2 \mathrm{PJ})$ in the winter time, and in the summer time they displace some production $(\sim 1.0 \mathrm{PJ})$ from CHP plants when the electricity price is low. This is also what is expected and hoped for by implementing the heat pumps in the district heating system. In the future, increased electricity production from non-dispatchable renewable energy sources, such as wind, is expected to result in greater fluctuations in electricity prices as illustrated in Figure 5. By implementing heat pumps, CHP plants are no longer forced to be in operation in order to supply heat when electricity prices are low.

The full load hours for the heat pumps in 2025 are shown in Figure 19. In general they are higher than the full load hours found for 2013. The heat pumps connected to the distribution network in most cases operate for roughly 4,000 FLH. The exceptions are the sea water heat pumps and the drinking water heat pump connected to the VEKV network (Roskilde).

In the case of the sea water heat pumps, the reason for this is the relatively lower COP compared to the other heat pumps. Particularly in February, the sea water heat pumps have a significant drop in heat production compared to the sewage water heat pumps, and the same occurs for the drinking water heat pumps. The reason is the high electricity price in February (see Figure 16). These high electricity prices have a significant impact on the heat production of sea 


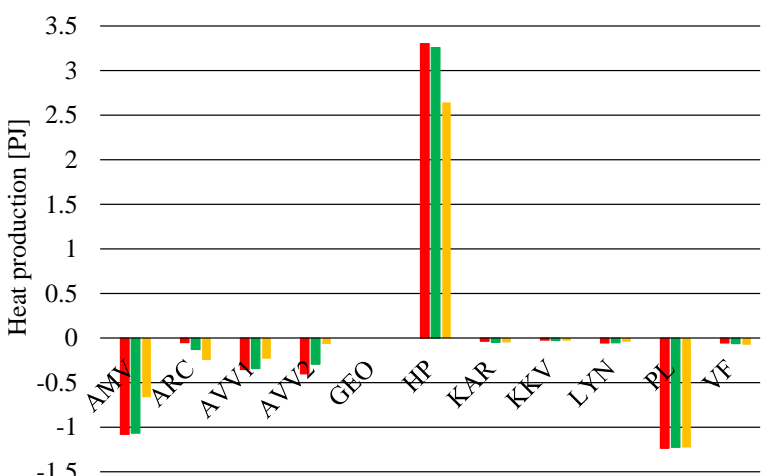

Fixed COP (dist.) $\quad$ Variable COP (dist.) $\quad$ Variable COP (trans.)

Figure 17: Difference in heat production from reference in 2025.

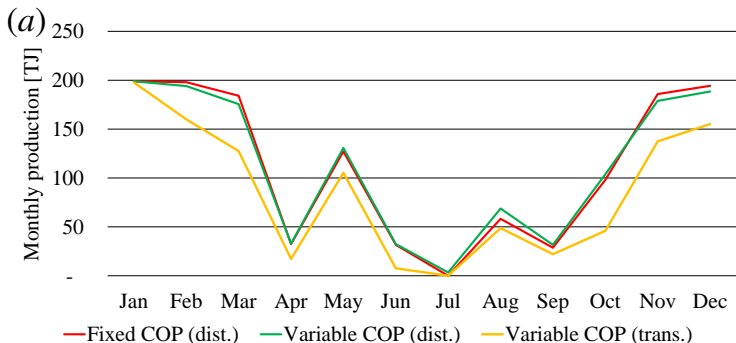

$($ b) 35
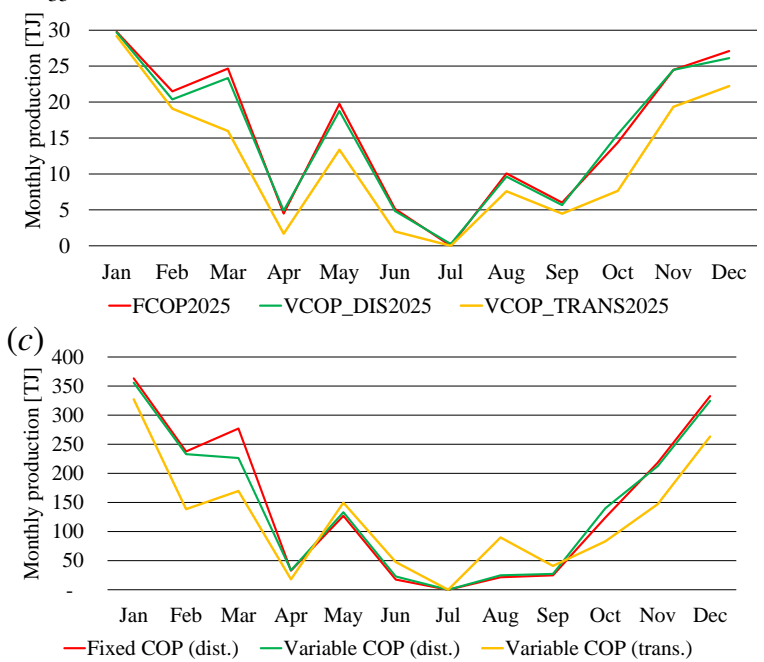

Figure 18: Total monthly heat production in 2025 for heat pumps using $(a)$ sewage water, $(b)$ drinking water, and $(c)$ sea water. 


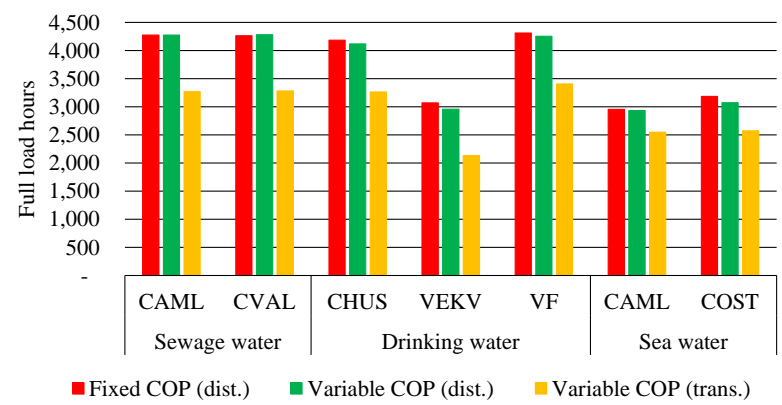

Figure 19: Full load hours for the heat pumps in 2025.

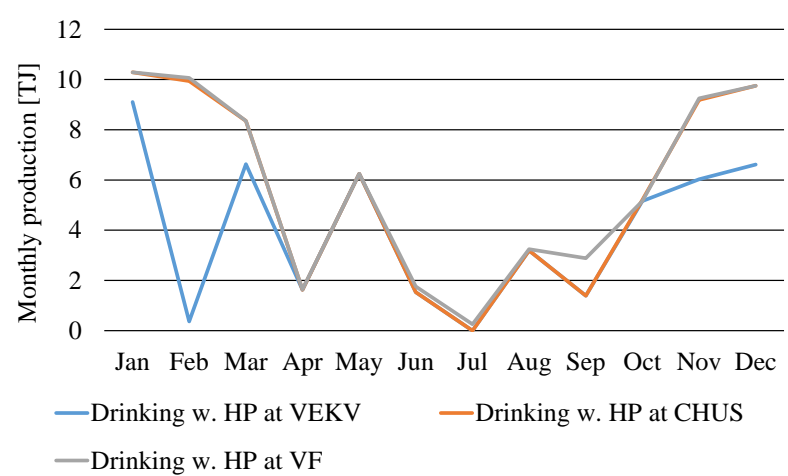

Figure 20: Total monthly heat production for the different drinking water heat pumps in 2025 for the Variable COP (dist.) scenario.

water heat pumps. Concerning the drinking water heat pumps, the higher prices only influence the heat production from the heat pump located in the VEKV area (see Figure 20). The reason for this is more competition in this particular area. VEKV is directly connected to AVV1, AVV2 and KARA, so when electricity prices are high, the AVV's units will run as much as possible, and KARA, which is a waste incineration plant, behaves like a 'must run' unit. This is not the case for the heat pump connected to the VF distribution network. The VF network is isolated (heat can be exported from this area but not imported due to higher network temperatures) and only has the VF plant and some peak load capacity. The heat pump will therefore operate as base load. The same is the case at CHUS. Other than a peak load boiler, the heat pump is the only directly connected unit. Both the heat pumps in the VF and CHUS networks operate for more than 700 hours in February, whereas the heat pump in VEKV only operates for 35 hours. This demonstrates the importance of having a model of the network that captures bottlenecks.

The heat pumps connected to the transmission network operate for roughly 3,000 full load hours for both the sewage water and drinking water heat pumps. The sea water heat pumps operate for roughly 2,500 full load hours. Lastly, the drinking water heat pump in VEKV connected to the transmission network only operates for roughly 2,000 full load hours. The lower production when connected to the transmission network can also be seen in Figure 18 , which shows the monthly heat production from the different heat pump technologies. In most cases they have a peak in March, May, and August. The production of the heat pumps connected to the transmission network is lower for all months apart from a few months for the sea water heat pumps. All heat pumps appear to be out of operation in July.

The production weighted COPs, or seasonal performance factors (SPF), are shown in Table 8. They are very close to the demand weighted COPs (Table 6) used for the fixed COP scenarios. 
Table 8: The seasonal performance factors (SPF) for the heat pumps.

\begin{tabular}{lcc}
\hline Technology/Source & SPF distr. & SPF trans. \\
\hline Sewage water & 3.2 & 2.5 \\
Drinking water & 3.1 & 2.6 \\
Sea water & 2.8 & 2.4 \\
\hline
\end{tabular}

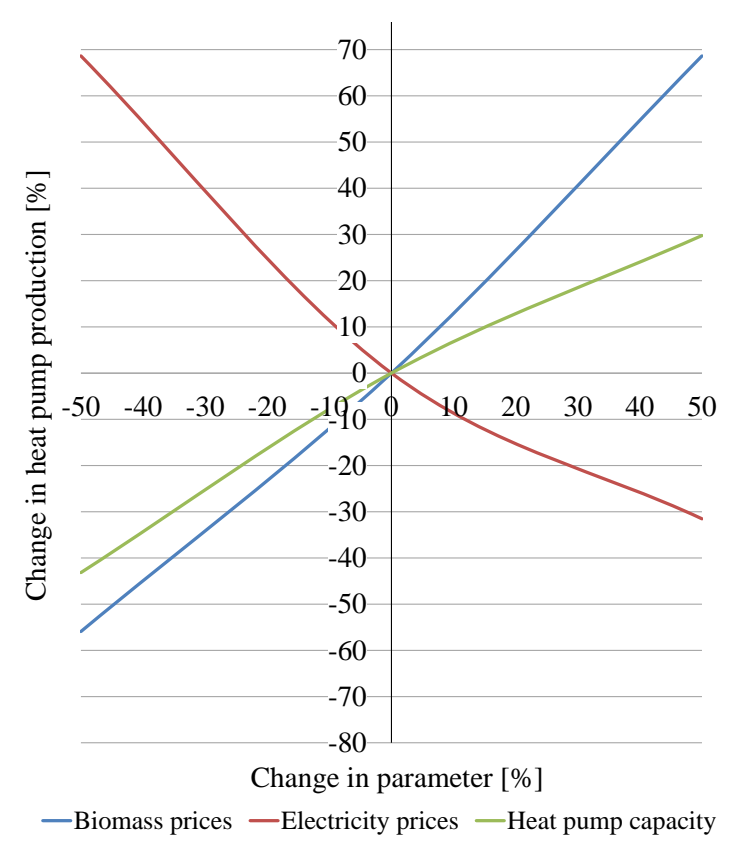

Figure 21: Sensitivity analysis of the results of the total heat pumps production for the 2025 Variable COP (dist.) scenario.

\subsection{Sensitivity analysis of scenario results}

Figure 21 depicts a sensitivity analysis of the heat pump production. The parameters (biomass prices, electricity prices, and total installed heat pump capacity) are increased and decreased by $50 \%$. In Figure 22 , the monthly production for the analysis is shown. A decrease in the electricity price or an increase in the biomass price by $50 \%$ will in both cases give a $70 \%$ increase in heat production from heat pumps. An increase in electricity prices by $50 \%$ will on the other hand only decrease the production by $30 \%$. By installing $50 \%$ more heat pump capacity in the system the total heat production by heat pumps only increases by $30 \%$. This is also reflected in a decrease in full load hours from 4,000 FLH to 3,500 FLH as extra capacity is only used during winter time (see Figure 22). If the biomass price decreases by $50 \%$, then the heat pumps are completely out of operation in the summer months.

The sensitivity analyses show that the heat production is highly dependent on the biomass and electricity prices. In the sensitivity analyses it is assumed that the electricity price is unaffected by the biomass price. This is, due to the fact, that the electricity price is the majority of the time set outside Denmark, where the marginal unit is based on fossil fuels.

\section{Discussion}

Concerning the methodology of the system analyses there are some aspect that deserve to be mentioned and discussed.

The VEKS distribution areas in the model (VEKV and VEKN) are, in reality, split into a number of smaller distribution areas. The CTR area description is more accurate, but an area such as CNOR still consists of three 


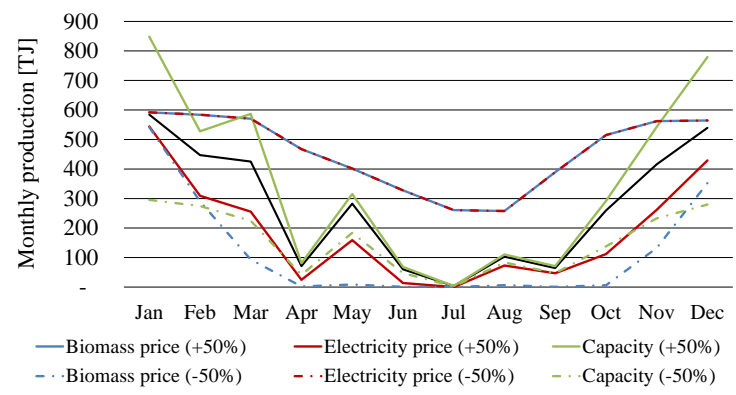

Figure 22: Sensitivity analysis for the total monthly heat production from all heat pumps in 2025. The black line depicts the original Variable COP (dist.) scenario results.

distribution areas in reality. As such, there is a risk that the real heat transmission between areas is likely not fully captured by the model. And of even greater relevance for this study, a heat pump connected to a distribution area is supplying a larger area than it in practice would, and thereby having an market advantage that it in reality would not have.

To decrease the simulation time, only one week in each month was simulated. The selected week was the last week of each month, and whether this week was representative of the month was not considered. This can, of course, give a number of problems. If the electricity price is very different in that week compared to the rest of the month, then the heat production from heat pumps will be very different. Balmorel utilises an outage sheet, which provides information regarding power plants with planned and forced outages. These outages will have a significant additional impact when only simulating certain weeks. Validation have however shown, that results were comparable to real life production levels of the various plants.

The 2025 simulation is based on a number of assumptions and forecasts. The forecasts and scenarios are based on reliable sources, such as IEA and the Danish Energy Agency, but prediction is difficult and there are many uncertainties in the inputs and assumptions used. Sensitivity analyses of biomass and electricity prices have, however, been done to analyse the impact of these assumptions.

The heat pump connected to the distribution network operates for roughly 3,000 FLH to 3,500 FLH in both the 2013 and 2025 scenarios. Connecting the heat pumps to the transmission network decreases the number to approximately 2,000 FLH to 2,500 FLH. Whether 3,000 FLH to 3,500 FLH is high enough to cover the yearly capital costs, will depend on the investment cost, internal rate, and fixed O\&M costs of the heat pump, and the future heat price (i.e future revenue).

In this study the existing Danish taxes and subsidies have been included when modeling the operation of the heat production units in the system. This is the most realistic case since no dramatic changes to the tax system are expected in the coming years. However, it could also have been interesting to analyse the system from a socio economic view i.e. without the existing taxes and subsidies to see how the regulatory framework affects the operation. Since electricity is taxed and biomass is subsidised in Denmark, a socio economic optimisation would probably be more advantageous to the heat pumps[9].

The monthly production is highly dependent on the COP, but the values of COP in the investigated heat pumps do not vary significantly over the year. For investigations involving air source heat pumps, modeling with an hourly COP, could on the other hand, be relevant.

Connecting the heat pumps to the transmission network instead of the distribution network decreases the number of full load hours of the heat pump drastically. The reason for this is the very high temperature in the transmission network, which yields a lower COP for the heat pumps. If the COP of the heat pumps connected to the transmission network were the same as the COP of those connected to the distribution network, then they would get at least the same amount of full load hours.

It would be favorable if the heat pumps could be connected to the transmission network. This is due to the fact that most large heat sources are near the sea (e.g. sea water and sewage water), and it would therefore not be possible to utilise the heat source potentials fully to supply inland areas with heat from heat pumps, if they are not connected 
to the transmission network. In the future, getting a higher COP with newer technologies (water vapour compression or hybrid heat pumps) might be possible.

It is important to take all aspects into account when evaluating the potential of different heat sources for heat pumps. One example of this is presented in Hubeck-Graudal (2015)[59] who finds that the potential of the drinking water network in Copenhagen is overestimated in MacAller (2013)[51] because the heat recovery from the ground after using the water as heat pump heat source is not sufficient to recover the temperature. This means that the additional heating will be required in the building as colder water enters.

Another suggestion for increasing the COPs of the heat pumps connected to the transmission network could be to lower the temperatures in the transmission network. Lowering the temperatures in this network would however pose a number of challenges[60].

Another idea could be to operate the heat pump with a constant temperature lift all year around, e.g. $55^{\circ} \mathrm{C}$ to $90^{\circ} \mathrm{C}$ $\left(\Delta T=35^{\circ} \mathrm{C}\right)$, and then boost the extra $10^{\circ} \mathrm{C}$ to $20^{\circ} \mathrm{C}$ with a boiler running on biomass or even electricity.

The results are develop for Copenhagen as a case, but they are valid for other cities with large-scale district heating implemented. However, it is important to notice the particularities of the Danish energy system before directly utilizing the results for other places. The studied energy system includes a high share of efficient CHP units based on biomass, waste and coal. These units produce heat and power at low cost, and make it difficult for heat pumps to compete. In addition energy prices and tax rules limits competivity of heat pumps. It is expected that the system will undergo significant changes in the coming years. These will include transition to renewables as wind power, solar heating, geothermal heating and biomass-based CHP. In addition, we assume that legal issues restricting profitability of heat pumps will be changed. Accordingly, for the future Copenhagen energy system the potential for implementation of heat pumps is expected be significantly improved and to higher extent to be limited by heat source accessibility, heat pump technology, and consumer demand. These changes are also assumed to make the Copenhagen system develop in the direction of similar cities, and thus making the results more readily applicable for other places.

\section{Conclusions}

This study investigated the potential for heat pump integration in the Greater Copenhagen district heating system, particularly the impact on the system of integrating heat pumps to the transmission and distribution networks of the district heating system, and the influence of modeling hourly fluctuations of the COP. Furthermore, realistic capacities, taking into account local heat sources, were modeled.

These operational data have been implemented in Balmorel, where a detailed representation of heat pumps has been modeled. This new representation can analyse the impact of fluctuating COP, and it enables the model to implement heat pumps in the distribution networks. The seasonal variation in COP is, however, not found to have a significant impact on the overall result. This is mainly because the COPs of water based heat pumps do not vary significantly throughout the year.

Due to the higher COP, connecting heat pumps to distribution networks results in a significantly higher heat production, than if connected to the transmission network. This can be seen from the higher number of full load hours achieved both now and in a near future. The reason is the lower temperature in the distribution networks, which results in a significantly higher COP of approximately 3 , compared to 2.5 when connected to the transmission network. This result in heat pumps having 3,500-4,000 full load hour and 2,500-3,000 full load hours when connected to the distribution and transmission networks, respectively. The heat pumps primarily displace peak load production in winter time, and some heat production from combined heat and power plants in summer time. Finally, it was shown that a significantly higher number of full load hours can be expected in a future with even more wind power in the system.

\section{Acknowledgements}

This work was partly funded by DONG Energy, Teknologisk Institut, Copenhagen Cleantech Cluster, and by DSF (Det Strategiske Forskningsråd) through the CITIES (no. 1035-00027B) and the 4DH project. 


\section{References}

[1] Danish Ministry of Energy and Climate, The Governments climate plan - on the way to a sociaty without greenhouse gases (Danish), URL http://www.ens.dk/klima-co2/regeringens-klimaplan 2013 (accessed February 9, 2016).

[2] City Council of Copenhagen, CPH 2025 Climate Plane - A green, smart og $\mathrm{CO}_{2}$ neutral city (Danish), URL http://kk.sites.itera. dk/apps/kk_pub2/pdf/930_QP7u8mn5bb.pdf 2013 (accessed February 9, 2016).

[3] D. Connolly, H. Lund, B. V. Mathiesen, M. Leahy, A review of computer tools for analysing the integration of renewable energy into various energy systems, Applied Energy 87 (2010) 1059-1082.

[4] T. Ommen, W. B. Markussen, B. Elmegaard, Heat pumps in combined heat and power systems, Energy 76 (2014) 989-1000.

[5] R. Lowe, Combined heat and power considered as a virtual steam cycle heat pump, Energy Policy 39 (2011) $5528-5534$.

[6] M. B. Blarke, The missing link in sustainable energy - Techno-economic consequences of large-scale heat pumps in distributed generation in favour of a domestic strategy for sustainable energy, Ph.D. thesis, Aalborg University, 2008.

[7] M. B. Blarke, H. Lund, Large-scale heat pumps in sustainable energy systems: system and project perspectives, Thermal Science 11 (2007) $143-152$.

[8] J. Kiviluoma, P. Meibom, Flexibility from district heating to decrease wind power integration costs, Tallinn, Estonia, Proceedings of the 12th International Symposium on District Heating and Cooling, 2010.

[9] M. Münster, P. E. Morthorst, H. V. Larsen, L. Bregnbæk, J. Werling, H. H. Lindboe, H. Ravn, The role of district heating in the future Danish energy system, Energy 48 (2012) 47-55.

[10] M. B. Blarke, Towards an intermittency-friendly energy system: Comparing electric boilers and heat pumps in distributed cogeneration, Applied Energy 91 (2012) 349-365

[11] T. Ommen, Heat pumps in CHP systems: High-efficiency Energy System Utilising Combined Heat and Power and Heat Pumps, Ph.D. thesis, Technical University of Denmark, 2015.

[12] P. J. Luickx, L. M. Helsen, W. D. D'haeseleer, Influence of massive heat-pump introduction on the electricity-generation mix and the GHG effect: Comparison between Belgium, France, Germany and The Netherlands, Renewable and Sustainable Energy Reviews 12 (2008) 2140 2158.

[13] V. Dagilis, Combined heat pump and power plant. Part I: Thermodynamic analysis, Mechanics 19 (2013) $172-177$.

[14] S. Dragićević, M. Bojić, An energy optimization model for a combined heat and power production energy supply system with a heat pump, Proceedings of the Institution of Mechanical Engineers, Part A: Journal of Power and Energy (SAGE Publications) 223 (4) (2009) $321-328$.

[15] S. Rinne, S. Syri, Heat pumps versus combined heat and power production as $\mathrm{CO}_{2}$ reduction measures in Finland, Energy 57 (2013) $308-318$.

[16] F. Bühler, F. M. Holm, B. Huang, J. G. Andreasen, B. Elmegaard, Mapping of low temperature heat sources in Denmark, Proceedings of ECOS 2015: 28th International Conference on Efficiency, Cost, Optimization, Simulation and Environmental Impact of Energy Systems, 2015.

[17] G. M. Reistad, Available energy conversion and utilization in the United States, Journal of Engineering for Gas Turbines and Power 97 (1975) 429-434.

[18] J. J. Bonilla, J. M. Blanco, L. Lopez, J. M. Sala, Technological recovery potential of waste heat in the industry of the Basque Country, Applied Thermal Engineering 17 (1997) 283-288.

[19] Z. Utlu, A. Hepbasli, A review on analyzing and evaluating the energy utilization efficiency of countries, Renewable and Sustainable Energy Reviews 11 (2007) 1-29.

[20] M. Dupont, E. Sapora, The heat recovery potential in the French industry: Which opportunities for heat pump systems?, Proceedings of the ECEEE Summer Study, 2009

[21] T. Ommen, W. B. Markussen, B. Elmegaard, Heat pumps in district heating networks, Proceedings of the CoolEnergy.dk 2013 conference: 2nd Symposium on Advances in Refrigeration and Heat Pump Technology, 2013.

[22] T. Ommen, W. B. Markussen, B. Elmegaard, Lowering district heating temperatures - Impact to system performance in current and future Danish energy scenarios, Energy 94 (2016) 273-291.

[23] K. Hedegaard, M. Münster, Influence of individual heat pumps on wind power integration - Energy system investments and operation, Energy Conversion and Management 75 (2013) 673-684.

[24] H. F. Ravn, M. Hindsberger, M. Petersen, R. Schmidt, R. Bøg, P. E. Grohnheit, H. V. Larsen, J. Munksgaard, J. Ramskov, M. R. Esop, G. Klavs, A. Galinis, R. Paprocki, M. Wawrzyszczuk, A. Gloukhov, Balmorel: A Model for Analyses of the Electricity and CHP Markets in the Baltic Sea Region, The Balmorel Project, ISBN: 87-986969-3-9, 2001.

[25] B. Cleary, A. Duffy, B. Bach, A. Vitina, A. O'Connor, M. Conlon, Estimating the electricity prices, generation costs and $\mathrm{CO}_{2}$ emissions of large scale wind energy exports from Ireland to Great Britain, Energy Policy 91 (2016) 38-48.

[26] Agora Energiwende, Increased Integration of the Nordic and German Electricity Systems, URL http://www.agora-energiewende. de/fileadmin/Projekte/2014/nordic-german-integration-project/Agora_Increased_Integration_Nordics_Germany_ SHORT_WEB.pdf 2015 (accessed February 9, 2016).

[27] Eastern Africa Power Pool, EAPP regional power system master plan - Volume I: Main report, URL http://ea-energianalyse.dk/ reports/1332/1332_eapp_master_plan_2014_volume_1_main_report.pdf 2014 (accessed February 9, 2016).

[28] China National Renewable Energy Centre (CNREC), High RE scenarios for China in 2050, URL/http://www . ens.dk/sites/ens.dk/ files/politik/Kina-samarbejdet/Aktiviteter/Scenarier/scenario_cnrec5.pdf 2011 (accessed February 9, 2016).

[29] W. Xiong, D. Zhang, P. Mischke, X. Zhang, Impacts of Renewable Energy Quota System on China's Future Power Sector, Energy Procedia 61 (2014) 1187-1190.

[30] H. F. Ravn, The Balmorel Model Structure - updated version 3.03 to be released mid 2016, URL http://balmorel. com/ 2016 (accessed February 9, 2016).

[31] HOFOR, Info: District heating (Homepage), URL http://www.hofor.dk/fjernvarme/ 2016 (accessed February 9, 2016).

[32] Ea Energy Analyses for CTR, HOFOR and VEKS, Heat Plan Greater Copenhagen phase 3 (Danish), URL http://www. varmeplanhovedstaden.dk/publikationer-og-moeder 2014 (accessed February 9, 2016). 
[33] Varmelast.dk, About the Heat Dispatch Units (Danish), URL http://www.varmelast.dk/da/om-varmelast/om-varmelast 2016 (accessed February 9, 2016).

[34] A. Verbruggen, P. Dewallef, S. Quoilin, M. Wiggin, Unveiling the mystery of Combined Heat \& Power (cogeneration), Energy 61 (2013) $575-582$.

[35] IEA, World Energy Outlook 2012, International Energy Agency, 2012.

[36] COWI and Ea Energy Analyses for the Danish Energy Agency, The role of district heating in the future Danish energy system (Danish), URL http://www.ens.dk/info/publikationer/fjernvarmens-rolle-fremtidige-energiforsyning 2014 (accessed February 9,2016$)$.

[37] Ea Energy Analyses for CTR, HOFOR and VEKS, Development of the heating market - Background report for VPH3 (Danish), URL http://www . varmeplanhovedstaden.dk/publikationer-og-moeder 2013 (accessed February 9, 2016).

[38] Nord Pool Spot, Historical Market Data, URL http://www.nordpoolspot.com/historical-market-data/ 2013 (accessed February 9, 2016).

[39] Ea Energy Analyses for the Baltic Sea Region Energy Co-operation (BASREC), Energy Policy Strategies of the Baltic Sea Region for the Post-Kyoto Period, URL http://basrec.net/projects/post-kyoto/ 2012 (accessed February 9, 2016).

[40] Danish Energy Agency, Preconditions for socio-economical analyses of the energy sector (Danish), URL http://www.ens.dk/ info/tal-kort/fremskrivninger-analyser-modeller/samfundsokonomiske-beregnings-forudsaetninger 2014 (accessed February 9, 2016).

[41] Nasdaq, Market prices - Nordic electricity, DSFuture, URL http://www.nasdaqomx.com/commodities/market-prices 2015 (accessed February 9, 2016).

[42] Danish Energy Association, Scenarios of electricity prices 2017-2035 - Analysis number 16 (Danish), URL http://www.danskenergi. dk/Analyse/Analyser/16_Elprisscenarier2017-2035.aspx 2014 (accessed February 9, 2016).

[43] Ea Energy Analyses for CTR, HOFOR and VEKS, VPH3 - The heating grid in the Greater Copenhagen area 2012 and 2025 (Danish), URL http://www.varmeplanhovedstaden.dk/publikationer-og-moeder 2013 (accessed February 9, 2016).

[44] B. Bach, Integration of heat pumps in Greater Copenhagen, MSc thesis at the Technical University of Denmark, 2014.

[45] I. Dincer, M. Kanoglu, Refrigeration Systems and Applications, John Wiley \& Sons, 2nd edn., 2010.

[46] HOFOR, Large electricity driven heat pumps for district heating, Presentation by Sannah Grüner at HOFOR about heat pumps in the heatning plan Greater Copenhagen project, 2013.

[47] Danish Meteorological Institute, Decadal mean weather - Weather data 2001-2010, URL http://www.dmi.dk/en/vejr/arkiver/ decadal-mean-weather/decadal-mean-weather/decadal-mean-weather/ 2014 (accessed February 9, 2016).

[48] K. Karlsson, P. Meibom, Optimal investment paths for future renewable based energy systems - Using the optimisation model Balmorel, International Journal of Hydrogen Energy 33 (2008) 1777-1787.

[49] HOFOR, Temperature data of the sewage water at Lynetten, Data of the hourly temperature data from Lynetten sewage treatment plant in the periods 2011 and 2012 provided by Sannah Grüner, HOFOR, 2013.

[50] Danish Meteorological Institute, Temperature data of the sea at Nordhavn, Data of the sea temperature near Copenhagen provided by Bent Vraae Jørgensen, DMI, 2013.

[51] S. A. MacAller, Potential for Heat Recovery from Danish Drinking Water Supply, MSc thesis at the Technical University of Denmark, 2013.

[52] Dong Energy, Svanemølleværket - Environmental accounting 2012 (Danish), URL http://www.dongenergy . com/da/sustainability_ /Pages/Groenne-regnskaber . aspx. Yearly statement on environmental impact, 2013 (accessed February 9, 2016).

[53] Dong Energy, Avedøreværket - Environmental accounting 2012 (Danish), URL http://www.dongenergy . com/da/sustainability_ /Pages/Groenne-regnskaber . aspx Yearly statement on environmental impact, 2013 (accessed February 9, 2016).

[54] Dong Energy, H.C. Ørsted værket - Environmental accounting 2012 (Danish), URL http://www.dongenergy.com/da/ sustainability_/Pages/Groenne-regnskaber.aspx Yearly statement on environmental impact, 2013 (accessed February 9, 2016).

[55] Amager Ressourcecenter, ARC - Environmental accounting 2012 (Danish), URL http://www.a-r-c.dk/media/123663/ miljoredegorelse_2012-pdf-.pdf. Yearly statement on environmental impact, 2013 (accessed February 9, 2016).

[56] Roskilde Forbrændingsanlæg, KARA/NOVEREN - Environmental accounting 2012 (Danish), URL http://www.karanoveren.dk/ karanoveren/organisation/groenne-regnskaber Yearly statement on environmental impact, 2013 (accessed February 9, 2016 ).

[57] Vattenfall, Amagerværket - Environmental accounting 2012 (Danish), URL http://corporate.vattenfall.dk/globalassets/ danmark/om_os/miljo/2012_amv_gr.pdf. Yearly statement on environmental impact, 2013 (accessed February 9, 2016).

[58] Lynettefællesskabet I/S, Lynetten and Damhusåen cleaning facilities - Environmental accounting 2012 (Danish), URL http: //www.lyn-is.dk/Lynettef\%C3\%A6llesskabet/Milj\%C3\%B8beretning,_Milj\%C3\%B8data_og_\%C3\%85rsberetning.aspx Yearly statement on environmental impact, 2013 (accessed February 9, 2016).

[59] H. Hubeck-Graudal, Feasibility of using the Copenhagen drinking water supply as a heat source in the district heating network, MSc thesis at the Technical University of Denmark, 2015.

[60] H. Li, S. J. Wang, Challenges in smart low-temperature district heating development, Energy Procedia 61 (2014) $1472-1475$. 